\section{(6) OPEN ACCESS}

\title{
Effect of secukinumab on clinical and radiographic outcomes in ankylosing spondylitis: 2-year results from the randomised phase III MEASURE 1 study
}

\author{
Jürgen Braun, ${ }^{1}$ Xenofon Baraliakos, ${ }^{1}$ Atul Deodhar, ${ }^{2}$ Dominique Baeten, ${ }^{3}$ \\ Joachim Sieper, ${ }^{4}$ Paul Emery, ${ }^{5}$ Aimee Readie, ${ }^{6}$ Ruvie Martin, ${ }^{6}$ Shephard Mpofu, ${ }^{7}$ \\ Hanno B Richards, ${ }^{7}$ for the MEASURE 1 study group
}

\section{Handling editor Tore K Kvien}

- Additional material is published online only. To view please visit the journal online (http://dx.doi.org/10.1136/ annrheumdis-2016-209730)

For numbered affiliations see end of article.

Correspondence to Professor Jürgen Braun, Department of Rheumatology, Rheumazentrum Ruhrgebiet, Claudiusstr. 45, Herne 44649, Germany; j.braun@ rheumazentrumruhrgebiet.de

Received 18 April 2016 Revised 18 November 2016 Accepted 20 November 2016 Published Online First 12 December 2016

\section{CrossMark}

To cite: Braun J Baraliakos X, Deodhar A et al. Ann Rheum Dis 2017;76:1070-1077.

\section{ABSTRACT}

Objective To evaluate the effect of secukinumab, an interleukin-17A inhibitor, on clinical signs and symptoms and radiographic changes through 2 years in patients with ankylosing spondylitis (AS).

Methods In the phase III MEASURE 1 study, patients were randomised to receive intravenous secukinumab $10 \mathrm{mg} / \mathrm{kg}$ (at baseline, week 2 and week 4) followed by subcutaneous secukinumab $150 \mathrm{mg}$ (intravenous $150 \mathrm{mg} ; \mathrm{n}=125$ ) or $75 \mathrm{mg}$ (intravenous $75 \mathrm{mg} ; \mathrm{n}=124$ ) every four weeks, or matched placebo $(n=122)$. Placebotreated patients were re-randomised to subcutaneous secukinumab 150 or $75 \mathrm{mg}$ from week 16. Clinical efficacy assessments included Assessment of SpondyloArthritis international Society 20 (ASAS20) response rates through week 104 . Radiographic changes at week 104 were assessed using the modified Stoke Ankylosing Spondylitis Spine Score (mSASSS).

Results $97(77.6 \%)$ and $103(83.1 \%)$ patients in the intravenous $150 \mathrm{mg}$ and intravenous $75 \mathrm{mg}$ groups, respectively, completed week 104 . In the full analysis set (intent-to-treat), ASAS20 response rates at week 104 were $73.7 \%$ and $68.0 \%$ in the intravenous $150 \mathrm{mg}$ and intravenous $75 \mathrm{mg}$ groups, respectively. Among patients with evaluable $X$-rays who were originally randomised to secukinumab $(n=168)$, mean change in mSASSS from baseline to week 104 was $0.30 \pm 2.53$. Serious adverse events were reported in $12.2 \%$ and $13.4 \%$ of patients in the $150 \mathrm{mg}$ and $75 \mathrm{mg}$ groups, respectively.

Conclusions Secukinumab improved AS signs and symptoms through 2 years of therapy, with no unexpected safety findings. Data from this study suggest a low mean progression of spinal radiographic changes, which will need to be confirmed in longer-term controlled studies.

Trial registration number NCT01358175.

\section{INTRODUCTION}

Ankylosing spondylitis (AS), a chronic inflammatory disease primarily affecting the axial skeleton, can be associated with progressive irreversible structural damage, resulting in functional deterioration. ${ }^{1-3}$ Long-term treatment goals are to maximise quality of life through control of signs and symptoms, prevention of structural damage and preservation of physical function. ${ }^{4}$

Tumour necrosis factor (TNF) inhibitors are the recommended pharmacotherapy for patients with high disease activity despite treatment with non-steroidal anti-inflammatory drugs (NSAIDs), ${ }^{4}$ based on their proven efficacy in improving signs, symptoms and physical function. ${ }^{6-10}$ However, up to $40 \%$ of patients do not respond to or cannot tolerate TNF inhibitors, ${ }^{11}$ and loss of efficacy can occur over time. ${ }^{12}$ Moreover, their effect on spinal osteoproliferative changes, a major component of structural damage in AS, is unclear. ${ }^{13-16}$

The pro-inflammatory cytokine interleukin-17A (IL-17A) is implicated in various pathophysiological features of spondyloarthritis, including inflammation and pathogenic bone remodelling. ${ }^{17-29}$ In placebo-controlled phase III studies, secukinumab, a fully human anti-IL-17A monoclonal antibody, significantly improved the signs and symptoms of psoriasis, ${ }^{30}$ psoriatic arthritis (PsA), ${ }^{31}$ and AS. ${ }^{32}$ Here, we present an update on the efficacy and safety of secukinumab in patients with AS during the non-controlled continuation phase of MEASURE 1 (NCT01358175) through 2 years. Results of exploratory radiographic endpoints at 2 years are also presented.

\section{METHODS}

\section{Study design and patients}

Study design and patient eligibility criteria have been described previously. ${ }^{32}$ Briefly, patients were $\geq 18$ years of age, with AS fulfilling the modified New York Criteria, and active disease as defined by a Bath Ankylosing Spondylitis Disease Activity Index (BASDAI) score of $\geq 4^{33}$ and a spinal pain score of $\geq 4 \mathrm{~cm}$ on a visual analogue scale $(0-10 \mathrm{~cm})$, despite treatment with maximal tolerated doses of NSAIDs. Patients who previously received one anti-TNF agent could enrol if they had an inadequate response or had stopped treatment for safety or tolerability reasons (anti-TNF-IR). Patients could continue on stable doses of sulfasalazine, methotrexate, prednisone and NSAIDs. Key exclusion criteria are detailed in the online supplementary materials.

Between 9 November 2011 and 21 January 2013, eligible patients were randomly assigned $(1: 1: 1)$ to one of two secukinumab arms or placebo (randomisation procedures are described in the online supplementary materials). Patients randomised to secukinumab received a $10 \mathrm{mg} / \mathrm{kg}$ intravenous infusion at baseline and weeks 2 and 4, 
followed by subcutaneous injections of $150 \mathrm{mg}$ (secukinumab intravenous $150 \mathrm{mg}$ ) or $75 \mathrm{mg}$ (intravenous $75 \mathrm{mg}$ ) every four weeks from week 8; patients in the placebo group were treated using the same intravenous-to-subcutaneous schedule. Placebo-treated patients were randomly reassigned $(1: 1)$ to receive secukinumab 150 or $75 \mathrm{mg}$ subcutaneous every four weeks from week 16 (non-responders) or week 24 (responders), with response based on Assessment of SpondyloArthritis international Society 20 (ASAS20) response criteria. ${ }^{3}$

\section{Procedures and end points}

Disease activity and efficacy assessments ${ }^{3} 3435$ were conducted at baseline and throughout the study, with key assessments at weeks 16 and 52 (as previously reported), ${ }^{32}$ and week 104; further details are provided in the online supplementary materials.

Lateral view radiographs of the cervical and lumbar spine were obtained at baseline and week 104. Images were digitised centrally and patient identifiers and temporal indicators removed to ensure blinding. Radiographs were scored using the modified Stoke Ankylosing Spondylitis Spine Score (mSASSS) method (total score range: $0-72$; see online supplementary materials for further details). ${ }^{36}$ Scoring was conducted by two central, independent readers, blinded with regard to treatment group and temporal sequence, who both read each film; statistical analyses used the mean score from the two readers. The top $5 \%$ of cases with the highest between-reader differences for change in radiographic score were identified for adjudication, with the two readers performing a third consensus read. Data from X-ray completers (patients with X-rays at both baseline and week 104) are presented as mean change from baseline to week 104.

Safety analyses assessed adverse events (AEs), serious AEs and routine laboratory values. Biochemical investigations were classified according to the Common Terminology Criteria for Adverse Events (V.4.03). ${ }^{38}$ Blood samples were collected at baseline through week 104 for assessment of secukinumab immunogenicity using a MesoScale Discovery bridging immunoassay. ${ }^{39}$

\section{Statistical analysis}

Clinical efficacy analyses at week 104 were carried out on data from patients originally randomised to secukinumab. Statistical analyses for binary variables up to week 104 used multiple imputation to account for missing data, while mixed-effect model repeated measures, with missing data assumed missing at random, were used for continuous variables (except highsensitivity C-reactive protein (hsCRP) was reported as observed). Data are also reported 'as observed' among patients with evaluable data. Radiographic analyses were assessed in X-ray completers who were initially randomised to secukinumab treatment, and in X-ray completers who switched from placebo to secukinumab at week 16 or 24 (placebo switchers). In each population, data were pooled between treatment groups.

\section{RESULTS}

\section{Patients}

Of 371 patients originally randomised to treatment, 97/125 (77.6\%) patients in the secukinumab intravenous $150 \mathrm{mg}$ group, $103 / 124(83.1 \%)$ in the intravenous $75 \mathrm{mg}$ group and $90 / 122$ $(73.8 \%)$ in the placebo group (no placebo given beyond week 24) completed week 104 . AEs (6.4\% of patients), lack of efficacy $(4.4 \%)$ and patient/guardian decision $(5.8 \%)$ were the main reasons for discontinuation among secukinumab-treated patients (see online supplementary figure S1).

Demographic and baseline characteristics have been reported previously. ${ }^{32}$ Mean time since diagnosis in the three randomised groups was 6.5-8.3 years, mean total BASDAI scores were 6.1-6.5 and median hsCRP levels were 7.4-9.2 mg/L. Approximately 73\% of patients were anti-TNF-naive.

Concomitant medications through 104 weeks were very similar to 52 weeks and baseline, and included sulfasalazine (35.0\%), methotrexate (15.8\%), systemic glucocorticoids (19.7\%) and NSAIDs (93.6\%).

\section{Clinical efficacy}

Among patients who continued on secukinumab treatment, ASAS20 and ASAS40 response rates similar to those achieved at weeks 16 and $52^{32}$ were observed at week 104 (figure $1 \mathrm{~A}, \mathrm{~B}$ ). ASAS20/40 response rates at week 104 (with multiple imputation of missing values) were $73.7 / 55.7 \%$, respectively, in the secukinumab intravenous $150 \mathrm{mg}$ group and $68.0 / 48.5 \%$ in the intravenous $75 \mathrm{mg}$ group (table 1). Response rates using observed data are reported in table 1. Improvements consistent with those reported previously at weeks 16 and $52^{32}$ were also observed in total BASDAI score (figure 1C) and all other secondary end points at week 104 (table 1).

In prespecified subgroup analyses, ASAS20 and ASAS40 response rates in both anti-TNF-naive and anti-TNF-IR patients were higher with secukinumab than placebo at week 16 (see online supplementary figure S2). Observed data showed that $59 / 69(85.5 \%)$ and $47 / 65(72.3 \%)$ anti-TNF-naive patients in the secukinumab intravenous $150 \mathrm{mg}$ and intravenous $75 \mathrm{mg}$ groups, respectively, achieved an ASAS20 response at week 104; an ASAS40 response was achieved by $48 / 69(69.6 \%)$ and $34 / 65$ $(52.3 \%)$ patients, respectively. In anti-TNF-IR patients, 10/18 $(55.6 \%)$ and 15/21 (71.4\%) patients achieved an ASAS20 response in the intravenous $150 \mathrm{mg}$ and intravenous $75 \mathrm{mg}$ groups, respectively, while $8 / 18$ (44.4\%) and 12/21 (57.1\%) patients achieved an ASAS40 response.

\section{Radiographic findings}

Of the 97 patients in the secukinumab intravenous $150 \mathrm{mg}$ group and 103 patients in the intravenous $75 \mathrm{mg}$ group who completed week 104, $86(88.7 \%)$ and $82(79.6 \%)$, respectively, had evaluable $\mathrm{X}$-rays at baseline and week 104 (X-ray completers) meeting predefined statistical analysis windows. Baseline characteristics of the X-ray completer cohort were similar between dose groups (table 2) and to those previously reported in the overall population. ${ }^{32}$ Overall, 104 (61.9\%) X-ray completers had syndesmophytes at baseline and 105 (62.5\%) had hsCRP >5 mg/ L. Baseline characteristics of the 89 placebo-switcher X-ray completers (see online supplementary table S1) were similar to those originally randomised to secukinumab.

Figure 2 shows the cumulative probability plot for change from baseline in mSASSS at week 104 among X-ray completers randomised to secukinumab at baseline. The change in mSASSS (mean $\pm \mathrm{SD}$ ) over 104 weeks was $0.30 \pm 2.53$ in the pooled secukinumab group, $0.30 \pm 1.94$ in the intravenous $150 \mathrm{mg}$ group and $0.31 \pm 3.04$ in the intravenous $75 \mathrm{mg}$ group (table 3 ). Changes among placebo switchers were $0.54 \pm 2.45$ (pooled), $0.44 \pm 2.09 \quad(150 \mathrm{mg})$ and $0.64 \pm 2.79 \quad(75 \mathrm{mg})$ (see online supplementary table S2 and figure S3). The smallest detectable change (SDC) was 1.838 and 2.814 at an $80 \%$ and $95 \%$ level of agreement, respectively. As defined by SDC at the $80 \%$ level of agreement, a large proportion of patients $(>80 \%)$ had no spinal radiographic progression. The Bland-Altman plot in online supplementary figure S4 shows the level of agreement between the two readers; variability was observed, particularly when an mSASSS change of $>0$ was recorded. The intraclass 


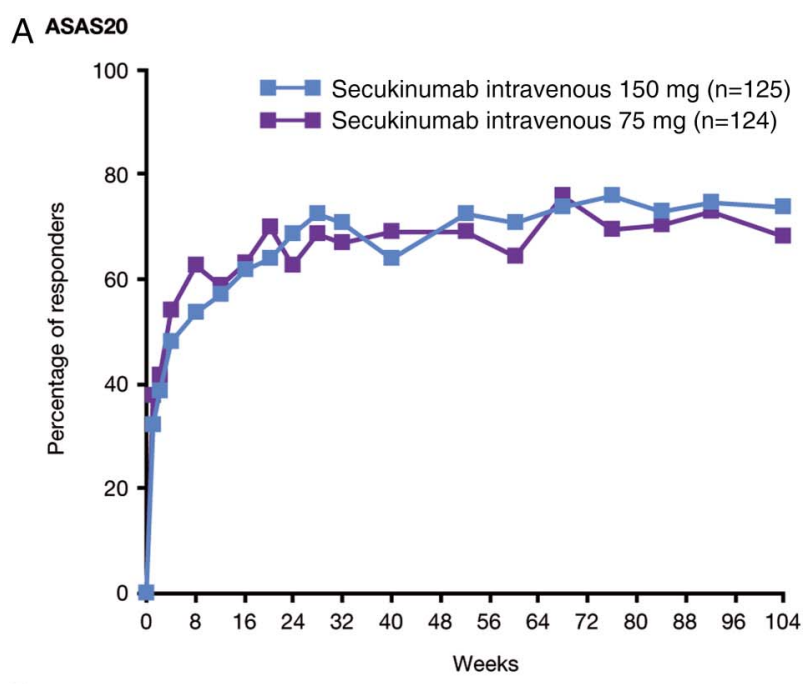

\section{B ASAS40}

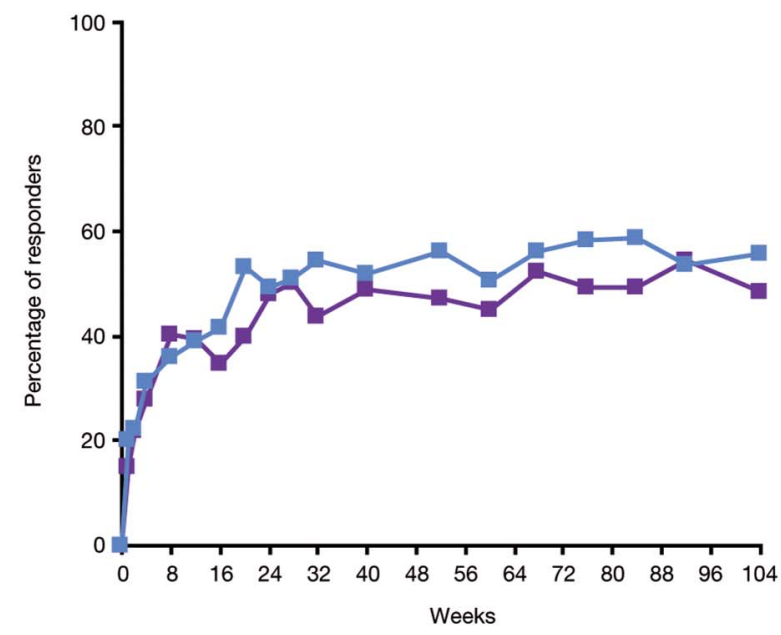

C BASDAI

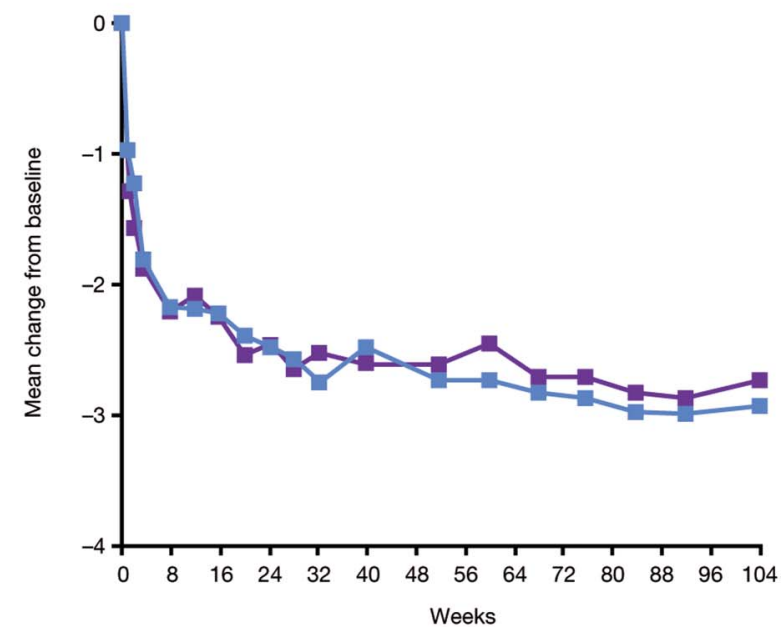

Figure 1 Summary of selected clinical efficacy end points through week 104 for patients randomised to secukinumab at baseline. Assessment of SpondyloArthritis international Society response criteria (ASAS20) (A) and ASAS40 (B) response rates, and mean change in total Bath Ankylosing Spondylitis Disease Activity Index (BASDAI) score (C) over time to week 104 is shown. Multiple imputation applied to handle missing data for ASAS20 and ASAS40, mixed-effects model repeated measures used for BASDAl. Patients received a $10 \mathrm{mg} / \mathrm{kg}$ loading dose of secukinumab at baseline and weeks 2 and 4, before receiving indicated dose of secukinumab subcutaneously every four weeks from week 8 . correlation coefficient (ICC) score for agreement between readers was 0.570 for change in mSASSS.

Baseline mSASSS was higher among patients with known predictors of radiographic progression compared with those without (table 3). Mean mSASSS change at week 104 among $\mathrm{X}$-ray completers randomised to secukinumab was higher in males than females, in those with baseline syndesmophytes versus those without, in patients with elevated versus normal baseline hsCRP levels and in smokers versus non-smokers (table 3). Among the X-ray completers who had no syndesmophytes at baseline and who were randomised to secukinumab, 61/64 (95.3\%), remained free from syndesmophytes at week 104 . Of the $104 \mathrm{X}$-ray completers with syndesmophytes at baseline, approximately $70 \%$ did not develop additional syndesmophytes through week 104 (see online supplementary table S3).

\section{Safety}

The most common AEs with secukinumab were nasopharyngitis, diarrhoea, headache, upper respiratory tract infections and pharyngitis (table 4). Discontinuations due to AEs were infrequent. The incidence of serious AEs was low, and similar between the two secukinumab groups (table 4; see online supplementary table S4).

One death was reported among secukinumab-treated patients throughout the study; on day 706, a patient in the intravenous $75 \mathrm{mg}$ group with a history of arterial hypertension and smoking died due to acute respiratory failure secondary to cardiac failure and pulmonary fibrosis. No suicides or suicidality-related AEs were reported among secukinumabtreated patients.

Candida infections were reported in four secukinumabtreated patients $(0.7$ cases per 100 patient-years of secukinumab exposure); two oral candidiasis (one in each dose group), one cutaneous Candida infection (150 mg group) and one genital candidiasis ( $75 \mathrm{mg}$ group). All four events were considered mild and non-serious, resolved spontaneously or with standard antifungal therapy, and did not result in study discontinuation. Herpes viral infections - mainly oral herpes and herpes zoster infections - were reported by $8.3 \%$ of patients in the $150 \mathrm{mg}$ group and $2.2 \%$ in the $75 \mathrm{mg}$ group. All cases were non-serious. One led to treatment discontinuation (herpes zoster infection in the $150 \mathrm{mg}$ group).

Grade 3 neutropenia occurred at a single visit in each of three patients receiving secukinumab $75 \mathrm{mg}$ and one receiving secukinumab $150 \mathrm{mg}$. Grade 4 neutropenia was reported in one patient ( $75 \mathrm{mg}$ group) at a single visit. None of these events led to treatment interruption or discontinuation. One grade 3 case was associated with a non-serious upper respiratory tract infection.

Crohn's disease was reported as a non-serious AE in four patients in the $75 \mathrm{mg}$ group (of whom two had a history of Crohn's disease and one a history of a polyp and colon adenoma) and one patient in the $150 \mathrm{mg}$ group, equivalent to 0.8 cases per 100 patient-years of secukinumab exposure. Two patients (one in each group; one with a history of Crohn's disease) discontinued because of an $\mathrm{AE}$ of Crohn's disease. A history of uveitis was reported in $62(16.7 \%)$ patients at baseline. An AE of uveitis was reported in 12 patients (seven with history of uveitis) on secukinumab, equivalent to 2.0 cases per 100 patient-years of secukinumab exposure. One was a serious $\mathrm{AE}$ (150 $\mathrm{mg}$ group); this resolved and did not require discontinuation of study treatment. Nineteen (5.1\%) patients had a history of psoriasis. Five patients reported an $\mathrm{AE}$ of psoriasis during the study (two on $75 \mathrm{mg}$, three on $150 \mathrm{mg}$ ), 
Table 1 Summary of efficacy data at week 104 among patients randomised to secukinumab at baseline

\begin{tabular}{|c|c|c|c|c|}
\hline \multirow[b]{2}{*}{ Efficacy end point } & \multicolumn{2}{|l|}{ Imputed } & \multicolumn{2}{|l|}{ Observed } \\
\hline & $\begin{array}{l}\text { Secukinumab } \\
\text { intravenous } 150 \mathrm{mg} \\
(\mathrm{n}=125)\end{array}$ & $\begin{array}{l}\text { Secukinumab } \\
\text { intravenous } 75 \mathrm{mg} \\
(\mathrm{n}=124)\end{array}$ & $\begin{array}{l}\text { Secukinumab } \\
\text { intravenous } 150 \mathrm{mg}\end{array}$ & $\begin{array}{l}\text { Secukinumab } \\
\text { intravenous } 75 \mathrm{mg}\end{array}$ \\
\hline ASAS40 response & $55.7 \%$ & $48.5 \%$ & $56 / 87(64.4 \%)$ & $46 / 86(53.5 \%)$ \\
\hline $\begin{array}{l}\text { hsCRP, median change from baseline } \\
(\min , \max )(\mathrm{mg} / \mathrm{L})\end{array}$ & $\mathrm{N} / \mathrm{A}$ & $\mathrm{N} / \mathrm{A}$ & $\begin{array}{l}-4.20(-143.6,50.0) \\
(n=88)\end{array}$ & $\begin{array}{l}-2.7(-97.5,30.2) \\
(n=87)\end{array}$ \\
\hline BASDAl, mean change from baseline & $-2.93(0.18)$ & $-2.75(0.18)$ & $\begin{array}{l}-3.41(2.12) \\
(\mathrm{n}=87)\end{array}$ & $\begin{array}{l}-3.04(1.81) \\
(\mathrm{n}=86)\end{array}$ \\
\hline SF-36 PCS score, mean change from baseline & $6.88(0.68)$ & $6.36(0.69)$ & $\begin{array}{l}8.06(8.08) \\
(n=87)\end{array}$ & $\begin{array}{l}7.41(6.83) \\
(n=85)\end{array}$ \\
\hline ASQoL score, mean change from baseline & $-4.38(0.45)$ & $-4.34(0.45)$ & $\begin{array}{l}-4.82(4.83) \\
(n=86)\end{array}$ & $\begin{array}{l}-4.58(4.44) \\
(n=85)\end{array}$ \\
\hline
\end{tabular}

Binary variables are reported using multiple imputation (percentage of responders) to account for missing data and as observed data ( $/ \mathrm{m}$ (\%), where $\mathrm{n}=$ number of patients with response and $m=$ number of patients with evaluable data). For continuous variables, mean change from baseline is reported as least-square mean change (SE) where mixed-effects model repeated measures analysis was performed and as observed data (SD). Patients received a $10 \mathrm{mg} / \mathrm{kg}$ loading dose of secukinumab at baseline and weeks 2 and 4 , before receiving indicated dose of secukinumab subcutaneously every four weeks from week 8.

ASAS, Assessment of SpondyloArthritis international Society response criteria; ASQoL, Ankylosing Spondylitis Quality of Life; BASDAl, Bath Ankylosing Spondylitis Disease Activity Index; hsCRP, high-sensitivity C-reactive protein; N/A, not available; SF-36 PCS, Short Form-36 physical component summary.

\begin{tabular}{|c|c|c|}
\hline Characteristic & $\begin{array}{l}\text { Secukinumab } \\
\text { intravenous } \\
150 \mathrm{mg} \\
(\mathrm{n}=86)\end{array}$ & $\begin{array}{l}\text { Secukinumab } \\
\text { intravenous } \\
75 \mathrm{mg} \\
(\mathrm{n}=82)\end{array}$ \\
\hline Age, mean (SD) years & $39.6(12.0)$ & $42.4(13.1)$ \\
\hline Male gender, $\mathrm{n}(\%)$ & $63(73.3)$ & $60(73.2)$ \\
\hline Weight, mean (SD) kg & $75.2(16.4)$ & $78.4(19.3)$ \\
\hline $\begin{array}{l}\text { Time since AS diagnosis, mean (SD) } \\
\text { years }\end{array}$ & $6.6(7.0)$ & $7.8(8.9)$ \\
\hline HLA-B27 positive, $n(\%)$ & $64(74.4)$ & $72(87.8)$ \\
\hline Current smoker, n (\%) & $25(29.1)$ & $17(20.7)$ \\
\hline Anti-TNF-naive, n (\%) & $60(69.8)$ & $62(75.6)$ \\
\hline \multicolumn{3}{|l|}{ Medication use at baseline, $\mathrm{n}(\%)$} \\
\hline Methotrexate & $14(16.3)$ & $12(14.6)$ \\
\hline Sulfasalazine & $27(31.4)$ & $32(39.0)$ \\
\hline Glucocorticoids & $13(15.1)$ & $10(12.2)$ \\
\hline hsCRP, median (min, max), mg/L & $7.8(0.2,147.7)$ & $9.7(0.4,100.0)$ \\
\hline Elevated hsCRP $>5 \mathrm{mg} / \mathrm{L}, \mathrm{n}(\%)$ & $55(64.0)$ & $50(61.0)$ \\
\hline Total BASDAl, mean (SD) & $6.2(1.6)$ & $6.0(1.5)$ \\
\hline BASFI, mean (SD) & $5.6(2.2)$ & $5.4(2.0)$ \\
\hline BASMI (linear), mean (SD) & $3.9(1.8)$ & $4.2(1.7)$ \\
\hline mSASSS, mean (SD) & $9.6(16.6)$ & $10.8(16.7)$ \\
\hline Syndesmophyte present, n (\%) & $51(59.3)$ & $53(64.6)$ \\
\hline Total back pain, mean (SD) & $63.9(17.2)$ & $63.3(18.6)$ \\
\hline $\begin{array}{l}\text { Patient's global assessment of disease } \\
\text { activity, mean (SD) }\end{array}$ & $64.6(17.7)$ & $60.5(18.6)$ \\
\hline
\end{tabular}

Data are $\mathrm{n}(\%)$, mean (SD), or median (minimum-maximum).

AS, ankylosing spondylitis; BASDAI, Bath Ankylosing Spondylitis Disease Activity Index; BASFI, Bath Ankylosing Spondylitis Functional Index; BASMI, Bath Ankylosing Spondylitis Metrology Index; HLA, human leucocyte antigen; hSCRP, high-sensitivity C-reactive protein; mSASSS, modified Stoke Ankylosing Spondylitis Spine Score; TNF, tumour necrosis factor. three of which were described as worsening or exacerbation of psoriasis. No psoriasis AEs were considered serious or required treatment interruption or discontinuation.

Four secukinumab-treated patients (two in each dose group) had cardiovascular events adjudicated as meeting major adverse cardiac event (MACE) criteria: three myocardial infarctions and one ischaemic stroke (see online supplementary table S5). None of these events led to treatment discontinuation. The incidence of MACE was 0.6 per 100 patient-years of secukinumab exposure.

Four cases of malignant/unspecified tumours were reported (0.6 per 100 patient-years of secukinumab exposure), all before week 52 , and have been described previously. ${ }^{32}$

Treatment-emergent anti-secukinumab antibodies were detected through week 104 in two patients in the secukinumab $150 \mathrm{mg}$ group; no neutralising antibodies were detected and neither patient experienced a loss of ASAS20 response.

\section{DISCUSSION}

This analysis demonstrates that secukinumab improves the clinical signs and symptoms of AS through 2 years of continued therapy. Secukinumab was effective in both anti-TNF-naive and anti-TNF-IR patients, although absolute response rates were generally higher in anti-TNF-naive patients. In contrast to the anti-TNF-naive subgroup, ASAS20 and ASAS40 response rates were highest with secukinumab intravenous $75 \mathrm{mg}$ in anti-TNF-IR patients. However, these results should be viewed in the context of the relatively small number of anti-TNF-IR patients, particularly at week 104 , and the heterogeneity of this subpopulation, which comprised patients who failed anti-TNF treatment for any one of several reasons, including lack of primary or secondary efficacy, or intolerance. Overall, given the lack of therapeutic alternatives, these findings indicate that secukinumab may address an unmet clinical need in 
Figure 2 Cumulative probability plot for change from baseline in the modified Stoke Ankylosing Spondylitis Spine Score (mSASSS) at week 104 in $\mathrm{X}$-ray completers randomised at baseline to secukinumab (observed data). X-ray completers are those patients with $\mathrm{X}$-rays at both baseline and at week 104 . Patients received a $10 \mathrm{mg} / \mathrm{kg}$ loading dose of secukinumab at baseline and weeks 2 and 4 , before receiving indicated dose of secukinumab subcutaneously every four weeks from week 8 .
Secukinumab intravenous $150 \mathrm{mg}(\mathrm{n}=86)$ - Secukinumab intravenous $75 \mathrm{mg}(\mathrm{n}=82)$

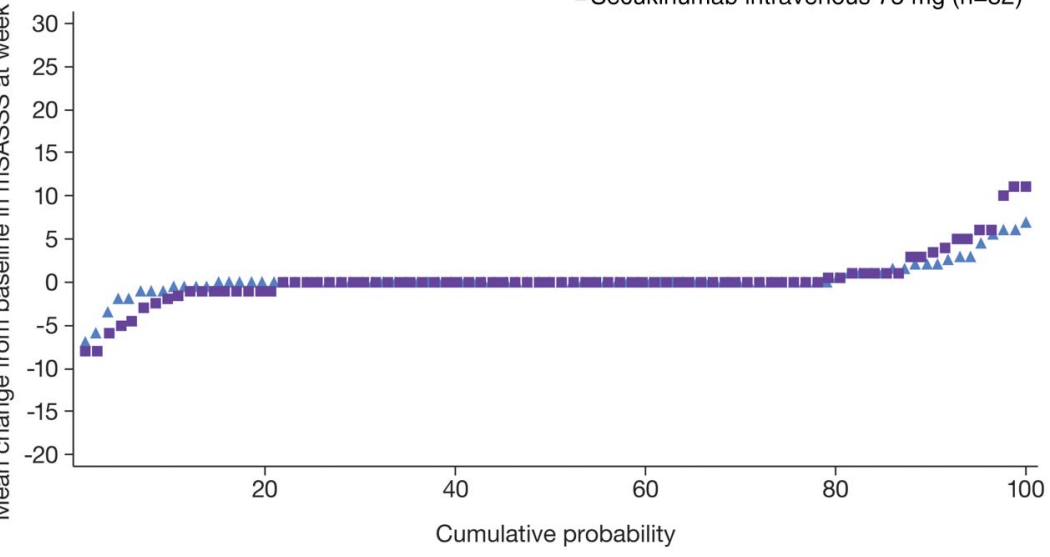

anti-TNF-IR patients, as well as providing a high level of efficacy as first-line therapy in anti-TNF-naive patients.

Prevention of structural damage is a long-term treatment goal in AS. The effect of anti-TNFs on radiographic progression in AS is unclear. mSASSS changes of $0.8-0.9$ over 2 years have been reported with TNF inhibitors in AS clinical trials compared with 0.9-1.3 in respective matched biologic-naive historical control cohorts from the Outcomes in AS International Study (OASIS). ${ }^{14-16}$ Authors concluded that the results do not provide evidence that anti-TNF therapy inhibits radiographic progression over 2 years. More recent studies have suggested that longer-term (approximately 8 years) treatment with an anti-TNF or earlier treatment initiation may be required to demonstrate an effect on radiographic progression. ${ }^{40} 41$ In the present study, the mean change in mSASSS through 2 years of secukinumab therapy was 0.30 (SD 2.53) overall, and 0.38-0.52 among patients with known predictors of radiographic progression at baseline, such as syndesmophytes or elevated CRP. ${ }^{42}$ Comparisons between these findings and those reported in the aforementioned studies and historical cohorts cannot be made because of differences in study designs and populations. Data from OASIS are from a period when treatment options were limited, and early TNF inhibitor trials are likely to have had more severe disease than those enrolled in MEASURE 1 and other recent placebocontrolled trials. Indeed, patients with evidence of radiographic progression are now more likely to be prescribed an approved TNF inhibitor than enter a clinical trial in which they might be randomised to placebo, and the anti-TNF trials included patients with longer disease duration $(\sim 10-11$ years vs $\sim 7$ years in X-ray completers $)^{8} \quad 14-16$ and more severe radiographic disease at baseline (mSASSS $\sim 16-20^{13-16}$ vs $\sim 10$ ) than in our study. Agreement between readers in mSASSS change was modest, with an ICC within the expected range of those reported from other studies. ${ }^{13-15} 43$ The Bland-Altman plot indicates that there is inter-reader variability, particularly where changes in mSASSS have occurred. The low overall rate of progression seen with secukinumab requires further exploration in long-term controlled studies before definite conclusions can be reached on whether anti-IL-17A therapy is effective in inhibiting mSASSS progression in patients with AS. Comparing radiographic changes associated with secukinumab with the historical cohorts, matched in terms of baseline disease, is also a possible area of future research.

Secukinumab showed an acceptable safety profile over 622.5 patient-years of exposure, with no new safety signals or unexpected safety findings compared with the first 52 weeks ${ }^{32}$ or with the safety profile reported in PsA and psoriasis. ${ }^{30} 31$ The incidence of AEs was higher with $150 \mathrm{mg}$ than with $75 \mathrm{mg}$, driven primarily by non-serious infections. Serious infections were infrequent in both secukinumab groups. Candida infections, a known risk with IL-17 inhibitors given the role of IL-17 in mucosal defence, ${ }^{44}$ were infrequent, mild and clinically manageable with antifungals. No dose dependence was observed for other safety risks. All four patients who reported MACE events on secukinumab treatment had pre-existing cardiovascular risk factors. The incidence of MACE in our study $(0.6$ per 100 patient-years) is consistent with reported data in AS. ${ }^{45}$

Spondyloarthritis is often associated with extra-articular manifestations such as uveitis, psoriasis and inflammatory bowel disease. $^{2}$ Patients with previous or stable presentation of these conditions could enrol in MEASURE 1 . The incidence of extraarticular manifestations reported as AEs in our study was low and consistent with expected rates in AS. IL-17A has been reported to have either a pathogenic or a protective role in Crohn's disease. ${ }^{46} 47$ The incidence of Crohn's disease in the present study (0.8 per 100 patient-years of secukinumab exposure) compares with reported rates of $0.2-1.3$ per 100 patientyears for TNF inhibitors in the AS population. ${ }^{48}$

Limitations of this analysis include the lack of comparator group beyond week 16, limiting interpretation of long-term findings to a comparison between secukinumab doses and to longitudinal evaluation. Despite the use of accepted statistical methods to account for missing data during the continuation period of the study, there remains a possible bias from the fact that patients who stay on study are those who do well on study treatment. Nevertheless, retention rates were high throughout the study and only $4.4 \%$ of patients withdrew because of lack of efficacy during the 2 -year period. The slow nature of radiographic disease progression in AS means long follow-up periods are required to show measureable changes. This prohibits the inclusion of a placebo comparator and can introduce confounding effects of concomitant treatment with other drugs that influence radiographic progression. ${ }^{49}$ Although blinded to treatment groups and sequence, readers were aware that all patients received secukinumab, possibly introducing an observational bias.

In conclusion, these longitudinal results from MEASURE 1 demonstrate that secukinumab provides similar levels of improvement in the clinical signs and symptoms of AS at 2 years as those previously reported during the short-term placebo-controlled period and provide the first uncontrolled 
Table 3 mSASSS in the X-ray completer cohort randomised to secukinumab at baseline

\begin{tabular}{|c|c|c|c|}
\hline Variable & $\begin{array}{l}\text { Secukinumab } \\
\text { intravenous } \\
150 \mathrm{mg}\end{array}$ & $\begin{array}{l}\text { Secukinumab } \\
\text { intravenous } \\
75 \mathrm{mg}\end{array}$ & $\begin{array}{l}\text { Secukinumab } \\
\text { pooled }\end{array}$ \\
\hline \multicolumn{4}{|c|}{ Overall population } \\
\hline Patients (n) & 86 & 82 & 168 \\
\hline Baseline & $9.63(16.63)$ & $10.84(16.69)$ & $10.22(16.62)$ \\
\hline $\begin{array}{l}\text { Change at } \\
\text { week } 104\end{array}$ & $0.30(1.94)$ & $0.31(3.04)$ & $0.30(2.53)$ \\
\hline \multicolumn{4}{|c|}{ Patients with syndesmophytes at baseline } \\
\hline Patients (n) & 51 & 53 & 104 \\
\hline Baseline & $16.12(19.09)$ & $16.69(18.32)$ & $16.41(18.61)$ \\
\hline $\begin{array}{l}\text { Change at } \\
\text { week } 104\end{array}$ & $0.49(2.50)$ & $0.45(3.77)$ & $0.47(3.20)$ \\
\hline \multicolumn{4}{|c|}{ Patients without syndesmophytes at baseline } \\
\hline Patients (n) & 35 & 29 & 64 \\
\hline Baseline & $0.17(0.56)$ & $0.16(0.40)$ & $0.16(0.49)$ \\
\hline $\begin{array}{l}\text { Change at } \\
\text { week } 104\end{array}$ & $0.01(0.19)$ & $0.03(0.33)$ & $0.02(0.26)$ \\
\hline \multicolumn{4}{|l|}{ Elevated hsCRP } \\
\hline Patients (n) & 55 & 50 & 105 \\
\hline Baseline & $11.57(17.69)$ & $14.22(19.16)$ & $12.83(18.36)$ \\
\hline $\begin{array}{l}\text { Change at } \\
\text { week } 104\end{array}$ & $0.48(2.25)$ & $0.46(3.08)$ & $0.47(2.66)$ \\
\hline \multicolumn{4}{|l|}{ Normal hsCRP } \\
\hline Patients (n) & 31 & 32 & 63 \\
\hline Baseline & $6.18(14.19)$ & $5.56(10.04)$ & $5.87(12.16)$ \\
\hline $\begin{array}{l}\text { Change at } \\
\text { week } 104\end{array}$ & $-0.03(1.16)$ & $0.06(3.00)$ & $0.02(2.27)$ \\
\hline \multicolumn{4}{|l|}{ Male } \\
\hline Patients (n) & 63 & 60 & 123 \\
\hline Baseline & $11.91(18.57)$ & $13.70(18.44)$ & $12.78(18.45)$ \\
\hline $\begin{array}{l}\text { Change at } \\
\text { week } 104\end{array}$ & $0.19(2.01)$ & $0.58(3.44)$ & $0.38(2.79)$ \\
\hline \multicolumn{4}{|l|}{ Female } \\
\hline Patients (n) & 23 & 22 & 45 \\
\hline Baseline & $3.39(6.44)$ & $3.05(5.68)$ & $3.22(6.02)$ \\
\hline $\begin{array}{l}\text { Change at } \\
\text { week } 104\end{array}$ & $0.59(1.73)$ & $-0.46(1.23)$ & $0.08(1.58)$ \\
\hline \multicolumn{4}{|c|}{ Smokers (at baseline) } \\
\hline Patients (n) & 25 & 17 & 42 \\
\hline Baseline & $13.10(19.45)$ & $10.88(9.20)$ & $12.20(16.00)$ \\
\hline $\begin{array}{l}\text { Change at } \\
\text { week } 104\end{array}$ & $-0.18(1.71)$ & $1.56(4.00)$ & $0.52(2.95)$ \\
\hline \multicolumn{4}{|c|}{ Non-smokers (at baseline) } \\
\hline Patients (n) & 61 & 65 & 126 \\
\hline Baseline & $8.21(15.28)$ & $10.83(18.21)$ & $9.56(16.84)$ \\
\hline $\begin{array}{l}\text { Change at } \\
\text { week } 104\end{array}$ & $0.49(2.00)$ & $-0.02(2.67)$ & $0.23(2.38)$ \\
\hline
\end{tabular}

$\mathrm{n}$ indicates number of patients with evaluable paired $\mathrm{X}$-ray data at both baseline and week 104 (X-ray completers). Data shown as mean (SD). mSASSS ranges from 0 to 72 with higher scores indicating greater radiographic damage. Patients received $10 \mathrm{mg} / \mathrm{kg}$ secukinumab at baseline and weeks 2 and 4 , before receiving indicated dose of secukinumab subcutaneously every four weeks from week 8 .

hsCRP, high-sensitivity C-reactive protein; mSASSS, modified Stoke Ankylosing Spondylitis Spine Score.

data on spinal radiographic progression in patients with AS under treatment with an IL-17A inhibitor. Long-term controlled studies are needed to evaluate whether secukinumab inhibits the progression of structural manifestations of AS.
Table 4 Incidence of treatment-emergent adverse events (AEs) during the entire treatment period through to week 104

\begin{tabular}{|c|c|c|c|}
\hline Variable & $\begin{array}{l}\text { Any } \\
\text { secukinumab } \\
150 \mathrm{mg} \\
(\mathrm{n}=181)^{*}\end{array}$ & $\begin{array}{l}\text { Any } \\
\text { secukinumab } \\
75 \mathrm{mg} \\
(\mathrm{n}=179)^{*}\end{array}$ & $\begin{array}{l}\text { Any } \\
\text { secukinumab } \\
\text { pooled } \\
(n=360)^{*}\end{array}$ \\
\hline $\begin{array}{l}\text { Exposure to study } \\
\text { treatment (days) } \dagger\end{array}$ & $621.3(187.5)$ & $642.0(180.9)$ & $631.6(184.3)$ \\
\hline \multicolumn{4}{|c|}{ Number of patients with event (\%) } \\
\hline Any $A E$ & $157(86.7)$ & $144(80.4)$ & $301(83.6)$ \\
\hline Serious AE $\ddagger$ & $22(12.2)$ & $24(13.4)$ & $46(12.8)$ \\
\hline $\begin{array}{l}\text { Any AE leading to } \\
\text { discontinuation§ }\end{array}$ & $17(9.4)$ & $8(4.5)$ & $25(6.9)$ \\
\hline $\begin{array}{l}\text { Infection or } \\
\text { infestation }\end{array}$ & $110(60.8)$ & $100(55.9)$ & $210(58.3)$ \\
\hline \multicolumn{4}{|c|}{ Common AEs (seen in $>5 \%$ of patients on secukinumab), $n(\%)$} \\
\hline Nasopharyngitis & $44(24.3)$ & 35 (19.6) & $79(21.9)$ \\
\hline Diarrhoea & $25(13.8)$ & $22(12.3)$ & $47(13.1)$ \\
\hline Headache & $22(12.2)$ & $20(11.2)$ & $42(11.7)$ \\
\hline $\begin{array}{l}\text { Upper respiratory tract } \\
\text { infection }\end{array}$ & $17(9.4)$ & $21(11.7)$ & $38(10.6)$ \\
\hline Pharyngitis & $21(11.6)$ & $12(6.7)$ & $33(9.2)$ \\
\hline Dyslipidaemia & $14(7.7)$ & $16(8.9)$ & $30(8.3)$ \\
\hline Influenza & $17(9.4)$ & $13(7.3)$ & $30(8.3)$ \\
\hline Oropharyngeal pain & $16(8.8)$ & $13(7.3)$ & $29(8.1)$ \\
\hline Arthralgia & $13(7.2)$ & $11(6.1)$ & $24(6.7)$ \\
\hline Back pain & $13(7.2)$ & $7(3.9)$ & $20(5.6)$ \\
\hline Leucopenia & $8(4.4)$ & $12(6.7)$ & $20(5.6)$ \\
\hline Cough & $10(5.5)$ & $9(5.0)$ & $19(5.3)$ \\
\hline Nausea & $10(5.5)$ & $9(5.0)$ & $19(5.3)$ \\
\hline \multicolumn{4}{|c|}{ AEs of special interest, $n$ (exposure-adjusted incidence rate per 100 patient-years } \\
\hline Candida infections & $2(0.7)$ & $2(0.6)$ & $4(0.7)$ \\
\hline Serious infections & $3(1.0)$ & $3(1.0)$ & $6(1.0)$ \\
\hline Crohn's disease & $1(0.3)$ & $4(1.3)$ & $5(0.8)$ \\
\hline $\begin{array}{l}\text { Major adverse cardiac } \\
\text { events (adjudicated) }\end{array}$ & $2(0.7)$ & $2(0.6)$ & $4(0.6)$ \\
\hline Malignancy & $3(1.0)$ & $1(0.3)$ & $4(0.6)$ \\
\hline $\begin{array}{l}\text { Neutropenia } \\
\text { (preferred term) }\end{array}$ & $9(3.1)$ & $14(4.8)$ & $23(3.9)$ \\
\hline
\end{tabular}

*Includes patients randomised to secukinumab at baseline and patients who were randomised to placebo who switched to secukinumab at weeks 16 or 24 .

tReported as mean (SD)

¥Serious AEs also include deaths.

§Up to week 104; an additional two patients discontinued secukinumab due to any AEs after week 104

ISystem organ class category.

\section{Author affiliations}

${ }^{1}$ Department of Rheumatology, Rheumazentrum Ruhrgebiet, Ruhr-University Bochum, Herne, Germany

${ }^{2}$ Division of Arthritis/Rheumatic Diseases (OPO9), Oregon Health \& Science University, Portland, Oregon, USA

${ }^{3}$ Department of Clinical Immunology and Rheumatology, Academic Medical Center/ University of Amsterdam, Amsterdam, The Netherlands

${ }^{4}$ Charité University Medicine Berlin, Berlin, Germany

${ }^{5}$ Leeds Musculoskeletal Biomedical Research Unit/Institute Rheumatic and Musculoskeletal Medicine, University of Leeds, Leeds, UK

${ }^{6}$ Department of Immunology and Dermatology, Novartis Pharmaceuticals Corporation, East Hanover, New Jersey, USA

${ }^{7}$ Department of Immunology and Dermatology, Novartis Pharma AG, Basel, Switzerland

Acknowledgements The authors acknowledge Sarah E Warner, Senior Director of Scientific and Medical Services for PAREXEL International Medical Imaging, for her expert advice on imaging throughout the trial. 
Contributors $J B, J S, D B, X B, A D, P E, H B R$, RM and $S M$ were involved in the design of the study. $D B, A D, J S$ and JB enrolled subjects into the study. All authors contributed to the analysis and interpretation of the data.

Funding This clinical trial was sponsored by Novartis Pharma AG. Medical writing support was provided by Chris Strutynskyj-Stannard, Joanne Fitz-Gerald, and Rugina Ali from Seren Communications, an Ashfield company, part of UDG Healthcare plc, the funding for which was provided by Novartis.

Competing interests JB has received honoraria for talks, advisory boards, paid consultancies and grants for studies from Abbott/AbbVie, Amgen, BMS, Boehringer Ingelheim, Celgene, Celltrion, Centocor, Chugai, EBEWE Pharma, Janssen, Medac, MSD (Schering-Plough), Mundipharma, Novartis, Pfizer (Wyeth), Roche, Sanofi-Aventis and UCB. XB has served as a consultant or paid speaker for or participated in clinical trials sponsored by AbbVie, Boehringer Ingelheim, Celgene, Centocor, Chugai, MSD, Novartis, Pfizer and UCB. AD has received research grants and honorarium for serving on the advisory boards of AbbVie, Amgen, Boehringer Ingelheim, Janssen, Novartis, Pfizer and UCB. DB has served as a consultant or paid speaker for or participated in clinical trials sponsored by AbbVie, BMS, Boehringer Ingelheim, Glenmark, Janssen, Eli Lilly, MSD, Novartis, Novo Nordisk, Pfizer, Roche and UCB. JS has served as a consultant or paid speaker for or participated in clinical trials sponsored by AbbVie, Janssen, Eli Lilly, Merck, Novartis, Pfizer and UCB. PE has participated in clinical trials for and provided expert advice to AbbVie, BMS, Eli Lilly, MSD, Novartis, Pfizer, Roche, Samsung, Takeda and UCB. AR, RM and HBR are employees of Novartis. AR and HBR own Novartis stock.

Patient consent Obtained.

Ethics approval The study was conducted in accordance with Good Clinical Practice and the principles of the Declaration of Helsinki.

Provenance and peer review Not commissioned; externally peer reviewed.

Data sharing statement A copy of the study protocol is available on request from the study sponsors.

Open Access This is an Open Access article distributed in accordance with the Creative Commons Attribution Non Commercial (CC BY-NC 4.0) license, which permits others to distribute, remix, adapt, build upon this work non-commercially, and license their derivative works on different terms, provided the original work is properly cited and the use is non-commercial. See: http://creativecommons.org/ licenses/by-nc/4.0/

\section{REFERENCES}

1 Ghasemi-Rad M, Attaya H, Lesha E, et al. Ankylosing spondylitis: a state of the art factual backbone. World J Radiol 2015;7:236-52.

2 Dougados M, Baeten D. Spondyloarthritis. Lancet 2011;377:2127-37.

3 Sieper J, Rudwaleit M, Baraliakos X, et al. The Assessment of SpondyloArthritis international Society (ASAS) handbook: a guide to assess spondyloarthritis. Ann Rheum Dis 2009;68(Suppl 2):ii1-44.

4 Braun J, van den Berg R, Baraliakos X, et al. 2010 update of the ASAS/EULAR recommendations for the management of ankylosing spondylitis. Ann Rheum Dis 2011;70:896-904.

5 Ward MM, Deodhar A, Akl EA, et al. American College of Rheumatology/Spondylitis Association of America/Spondyloarthritis Research and Treatment Network 2015 Recommendations for the Treatment of Ankylosing Spondylitis and Nonradiographic Axial Spondyloarthritis. Arthritis Rheumatol 2016;68:282-98

6 van der Heijde D, Kivitz A, Schiff MH, et al. Efficacy and safety of adalimumab in patients with ankylosing spondylitis: results of a multicenter, randomized, double-blind, placebo-controlled trial. Arthritis Rheum 2006:54:2136-46.

7 Davis JC Jr, van der Heijde D, Braun J, et al. Recombinant human tumor necrosis factor receptor (etanercept) for treating ankylosing spondylitis: a randomized, controlled trial. Arthritis Rheum 2003;48:3230-6.

8 Inman RD, Davis JC Jr, van der Heijde $\mathrm{D}$, et al. Efficacy and safety of golimumab in patients with ankylosing spondylitis: results of a randomized, double-blind, placebo-controlled, phase III trial. Arthritis Rheum 2008:58:3402-12.

9 van der Heijde D, Dijkmans B, Geusens P, et al., Ankylosing Spondylitis Study for the Evaluation of Recombinant Infliximab Therapy Study Group. Efficacy and safety of infliximab in patients with ankylosing spondylitis: results of a randomized, placebo-controlled trial (ASSERT). Arthritis Rheum 2005;52: 582-91

10 Landewé R, Braun J, Deodhar A, et al. Efficacy of certolizumab pegol on signs and symptoms of axial spondyloarthritis including ankylosing spondylitis: 24-week results of a double-blind randomised placebo-controlled Phase 3 study. Ann Rheum Dis 2014:73:39-47.

11 Braun J, Kiltz U, Heldmann F, et al. Emerging drugs for the treatment of axial and peripheral spondyloarthritis. Expert Opin Emerg Drugs 2015:20:1-14.

12 Baraliakos X, Listing J, Fritz C, et al. Persistent clinical efficacy and safety of infliximab in ankylosing spondylitis after 8 years-early clinical response predicts long-term outcome. Rheumatology (Oxford) 2011;50:1690-9.
13 Braun J, Baraliakos X, Hermann KG, et al. The effect of two golimumab doses on radiographic progression in ankylosing spondylitis: results through 4 years of the GO-RAISE trial. Ann Rheum Dis 2014;73:1107-13.

14 van der Heijde D, Salonen D, Weissman BN, et al. Assessment of radiographic progression in the spines of patients with ankylosing spondylitis treated with adalimumab for up to 2 years. Arthritis Res Ther 2009;11:R127.

15 van der Heijde D, Landewé R, Baraliakos $X$, et al. Radiographic findings following two years of infliximab therapy in patients with ankylosing spondylitis. Arthritis Rheum 2008;58:3063-70.

16 van der Heijde D, Landewé R, Einstein S, et al. Radiographic progression of ankylosing spondylitis after up to two years of treatment with etanercept. Arthritis Rheum 2008;58:1324-31.

17 Appel H, Maier R, Wu P, et al. Analysis of IL-17(+) cells in facet joints of patients with spondyloarthritis suggests that the innate immune pathway might be of greater relevance than the Th17-mediated adaptive immune response. Arthritis Res Ther 2011;13:R95

18 Bowness P, Ridley A, Shaw J. Th17 cells expressing KIR3DL2+ and responsive to HLA-B27 homodimers are increased in ankylosing spondylitis. J Immunol 2011;186:2672-80.

19 DeLay ML, Turner MJ, Klenk El, et al. HLA-B27 misfolding and the unfolded protein response augment interleukin-23 production and are associated with Th17 activation in transgenic rats. Arthritis Rheum 2009;60:2633-43.

20 Glatigny S, Fert I, Blaton MA, et al. Proinflammatory Th17 cells are expanded and induced by dendritic cells in spondylarthritis-prone HLA-B27-transgenic rats. Arthritis Rheum 2012;64:110-20

21 Kenna TJ, Davidson SI, Duan R, et al. Enrichment of circulating interleukin-17-secreting interleukin-23 receptor-positive $\gamma / \delta$ T cells in patients with active ankylosing spondylitis. Arthritis Rheum 2012:64:1420-9.

22 Noordenbos T, Yeremenko N, Gofita I, et al. Interleukin-17-positive mast cells contribute to synovial inflammation in spondylarthritis. Arthritis Rheum 2012:64:99-109.

23 Sarin R, Wu X, Abraham C. Inflammatory disease protective R381Q IL23 receptor polymorphism results in decreased primary CD4+ and CD8+ human T-cell functional responses. Proc Natl Acad Sci USA 2011;108:9560-5.

24 Shen H, Goodall JC, Hill Gaston JS. Frequency and phenotype of peripheral blood Th17 cells in ankylosing spondylitis and rheumatoid arthritis. Arthritis Rheum 2009:60:1647-56.

25 Sherlock JP, Joyce-Shaikh B, Turner SP, et al. IL-23 induces spondyloarthropathy by acting on ROR- $\gamma \mathrm{t}+\mathrm{CD} 3+\mathrm{CD} 4-\mathrm{CD} 8-$ entheseal resident T cells. Nat Med 2012;18:1069-76.

26 van Tok M, van Duivenvoorde L, Kramer I, et al. Anti-IL-17A treatment blocks inflammation, destruction and new bone formation in experimental spondyloarthritis in HLA-B27 transgenic rats [abstract]. Arthritis Rheumatol 2015;67(Suppl 10). http:/l acrabstracts.org/abstract/anti-il-17a-treatment-blocks-inflammation-destruction-andnew-bone-formation-in-experimental-spondyloarthritis-in-hla-b27-transgenic-rats/ (accessed 22 Dec 2015).

27 Chao CC, Chen SJ, Adamopoulos IE, et al. Anti-IL-17A therapy protects against bone erosion in experimental models of rheumatoid arthritis. Autoimmunity 2011;44:243-52

28 Adamopoulos IE, Chao CC, Geissler R, et al. Interleukin-17A upregulates receptor activator of NF-kappaB on osteoclast precursors. Arthritis Res Ther 2010;12:R29.

29 Koenders MI, Lubberts E, Oppers-Walgreen B, et al. Blocking of interleukin-17 during reactivation of experimental arthritis prevents joint inflammation and bone erosion by decreasing RANKL and interleukin-1. Am J Pathol 2005; 167:141-9.

30 Langley RG, Elewski BE, Lebwohl $M$, et al. Secukinumab in plaque psoriasisresults of two phase three trials. N Engl J Med 2014;371:326-8.

31 Mease PJ, Mclnnes IB, Kirkham B, et al. Secukinumab inhibition of interleukin-17A in patients with psoriatic arthritis. N Engl J Med 2015:373:1329-3.

32 Baeten D, Sieper J, Braun J, et al., on behalf of the MEASURE 1 and MEASURE 2 Study Groups. Secukinumab interleukin-17A inhibition in ankylosing spondylitis. N Engl J Med 2015;373:2534-48

33 Garrett S, Jenkinson T, Kennedy LG, et al. A new approach to defining disease status in ankylosing spondylitis: the Bath Ankylosing Spondylitis Disease Activity Index. J Rheumatol 1994;21:2286-91.

34 Ware JE, Kosinski M, Dewey JE. How to score Version Two of the SF-36 Health Survey. Lincoln, RI: Quality Metric, 2000.

35 Doward LC, Spoorenberg A, Cook SA, et al. Development of the ASQoL: a quality of life instrument specific to ankylosing spondylitis. Ann Rheum Dis 2003;62:20-6.

36 Creemers MC, Franssen MJ, van't Hof MA, et al. Assessment of outcome in ankylosing spondylitis: an extended radiographic scoring system. Ann Rheum Dis 2005:64:127-9.

37 Baraliakos $\mathrm{X}$, Listing J, Rudwaleit $\mathrm{M}$, et al. Progression of radiographic damage in patients with ankylosing spondylitis: defining the central role of syndesmophytes. Ann Rheum Dis 2007:66:910-15.

38 Common Terminology Criteria for Adverse Events (CTCAE) version 4.03 June 2010 (http:// evs.nci.nih.gov/ftp1/CTCAE/CTCAE_4.03_2010-06-14_QuickReference_5x7.pdf). 
39 Klein $U$, Liang $E$, Vogel $B$, et al. Immunogenicity of the novel anti-il-17a antibody, secukinumab, with intravenous and subcutaneous dosing regimens in healthy subjects and patients. Ann Rheum Dis 2013;72(Suppl 3):630.

40 Haroon $\mathrm{N}$, Inman RD, Learch TJ, et al. The impact of tumor necrosis factor $\alpha$ inhibitors on radiographic progression in ankylosing spondylitis. Arthritis Rheum 2013;65:2645-54.

41 Baraliakos $\mathrm{X}$, Haibel $\mathrm{H}$, Listing J, et al. Continuous long-term anti-TNF therapy does not lead to an increase in the rate of new bone formation over 8 years in patients with ankylosing spondylitis. Ann Rheum Dis 2014;73:710-15.

42 Poddubnyy $\mathrm{D}$, Haibel $\mathrm{H}$, Listing J, et al. Baseline radiographic damage, elevated acute-phase reactant levels, and cigarette smoking status predict spinal radiographic progression in early axial spondylarthritis. Arthritis Rheum 2012;64:1388-98.

43 Sieper J, Listing J, Poddubnyy D, et al. Effect of continuous versus on-demand treatment of ankylosing spondylitis with diclofenac over 2 years on radiographic progression of the spine: results from a randomised multicentre trial (ENRADAS). Ann Rheum Dis 2016;75:1438-43.
44 Puel A, Cypowyj S, Bustamante J, et al. Chronic mucocutaneous candidiasis in humans with inborn errors of interleukin-17 immunity. Science 2011;332:65-8.

45 Mathieu S, Gossec L, Dougados M, et al. Cardiovascular profile in ankylosing spondylitis: a systematic review and meta-analysis. Arthritis Care Res (Hoboken) 2011;63:557-63.

46 Skroza N, Proietti I, Pampena R, et al. Correlations between psoriasis and inflammatory bowel diseases. Biomed Res Int 2013;2013:983902.

47 O'Connor W Jr, Kamanaka M, Booth CJ, et al. A protective function for interleukin 17A in T cell-mediated intestinal inflammation. Nat Immunol 2009;10:603-9.

48 Braun J, Baraliakos $X$, Listing J, et al. Differences in the incidence of flares or new onset of inflammatory bowel diseases in patients with ankylosing spondylitis exposed to therapy with anti-tumor necrosis factor alpha agents. Arthritis Rheum 2007:57:639-47.

49 van der Heijde $D$, Landewé $R$, van der Linden S. How should treatment effect on spinal radiographic progression in patients with ankylosing spondylitis be measured? Arthritis Rheum 2005;52:1979-85. 